DOI: $10.15503 /$ onis2012-309-314

\title{
„...TAK JAK ODCISKA SIĘ W WOSKU PIECZĘĆ" Mnemotechnika w Kazaniach Peregryna z Opola
}

\author{
Marcin KiEebus \\ marcinkielbus@gmail.com
}

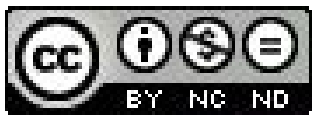

Pod koniec XII w. odrodził się ruch wędrownych głosicieli ewangelii. Jednak papiestwo zajęło wobec niego postawę co najmniej ostrożna, upatrując wręcz w ówczesnych kaznodziejach ludowych pewne zagrożenie zarówno dla hierarchii kościelnej, jak i dla doktryny. Obawy Rzymu budziła bowiem zarówno pojawiająca się krytyka bogactwa kleru, jak i poziom znajomości dogmatów. Remedium według papiestwa miało stanowić zatwierdzenie nowych zakonów, posiadających oficjalne prawo głoszenia kazań. Od tych świeżych struktur mniszych, mających w zamierzeniu wyprzeć nieokiełznany nurt ludowych ewangelistów, kolejni biskupi Rzymu wymagali bezwzględnego posłuszeństwa oraz dobrej znajomości nauk Kościoła zapewnionej przez obowiązkową edukację. Ogólny wzrost wykształcenia zakonników-kaznodziejów pociągnął za sobą rozwój teoretyczny kaznodziejstwa. Pojawiły się podręczniki normujące zarówno treść, jak i budowę tekstów. W rezultacie układanie kazań urosło do rangi skomplikowanej sztuki (ars praedicandi). Dobre kazanie miało być kazaniem skutecznym, czyli takim, które przekonuje lub pogłębia wiarę, ale zarazem nigdy nie pozostawia obojętnym odbiorcę, co zapewnić miała precyzja budowy i siła argumentów.

Jednym z najwcześniejszych przykładów realizacji tej sztuki na ziemiach polskich są zbiory de tempore i de sanctis ułożone u schyłku XIII stulecia przez Peregryna z Opola. Istotny jest również fakt, że Peregryn należał do dominikanów, czyli do Zakonu Kaznodziejów (Ordo Praedicatorum), programowo zajmującego się duszpasterstwem. Przyjrzyjmy się zatem jego twórczości, używając do tego jednego z kazań1.

Zgodnie z zasadami ${ }^{2}$ Peregryn zawsze zaczyna od tematu (thema), którym jest fragment Biblii. I tak w kazaniu Na drugq niedziele po zestaniu Ducha Św. jest nim pierwszy werset przypowieści z Ewangelii wg św. Łukasza $(14,16)$ : „Pewien człowiek wyprawił wielką ucztę i zaprosił wielu". Dalej powinno nastąpić wyeksponowanie wybranych składników tematu (divisio), którym zostanie przydany sens przenośny (sensus spiritualis). W tym konkretnym przypadku, Peregryn z Opola prezentuje dwa główne punkty (in his verbis possunt duo notari): po pierwsze hojność Boga, którego w przytoczonym wersecie ma symbolizować ów „pewien człowiek”; po drugie - „przewrotność tych, którzy nie przyjęli zaproszenia na ucztę", o czym jest mowa bezpośrednio w dalszej części Ewangelii (Łk 14, 18-24), którą kaznodzieja przytoczy później w miejscu rozwijania tego wątku. Do tych dwóch punktów Peregryn dodaje jeszcze zdefiniowanie samej uczty jako Sądu Ostatecznego, co można umownie potraktować jako punkt trzeci - szczególnie bowiem ceniono wyławianie z tematu trzech elementów. Dlaczego więc od razu zamiast in his verbis possunt duo notari nie napisał tria notari? Otóż w ten sposób wyniósł on wagę stron (gospodarz-goście) ponad samo spotkanie, tworząc hierarchię, w której podmioty górują nad miejscem i okolicznościami.

1 Podstawą niniejszego szkicu jest tekst wydany przez R. Tatarzyńskiego: Peregrini de Opole, Sermones de tempore et de sanctis, Warszawa 1997, s. 187-193; oraz przekład J. Mrukówny: Peregryn z Opola, Kazania "de tempore" $i$ "de sanctis", Kraków - Opole 2001, s. 215-221.

2 Schemat kazania zob. J. Wolny, Łaciński zbiór kazań Peregryna z Opola i ich związek z tzw. „Kazaniami gnieźnieńskimi”, [w:] J. Lewański (red.), Średniowiecze. Studia o kulturze, Warszawa 1961, s. 176-179. 
Wydzielone w początkowej części elementy tematu są rdzeniem, który kaznodzieja, zgodnie z zasadami ars praedicandi, powinien w kolejnej partii tekstu (dilatatio) obudować powagą autorytetów (auctores), przykładami (exempla) czy też innymi dowodami.

Najpierw jednak Peregryn konstruuje formę przejścia, którym jest przywołanie analogicznej do Ewangelii wg św. Eukasza sceny ucztowania z Księgi Rodzaju (Rdz 43, 32). Zgodnie bowiem $\mathrm{z}$ tradycja, upatrującą w Starym Testamencie prefigurację Nowego, Peregryn przedstawia Józefa wydającego ucztę dla braci jako zapowiedź Chrystusa w dniu Sądu Ostatecznego, a odsuniętych od uczty Egipcjan jako grzeszników. Wprowadzenie Chrystusa do kazania i utożsamienie Go z gospodarzem jest tu przejawem nowego i głębszego, bo bardziej indywidualnego, chrystocentryzmu, który w XIII w. z powodzeniem upowszechnia się dzięki działalności młodych zakonów, w tym również dzięki Zakonowi Kaznodziejów.

Po tym zabiegu Peregryn przystępuje do dalszej realizacji schematu kazania, czyli do rozwinięcia pierwszego punktu tematu, którym jest hojność Gospodarza-Zbawiciela. Jednocześnie dokonuje kolejnego przejścia, pisząc: „Hojność (...) Chrystusa przejawia się w tym, że wyprawił ucztę wielką" (largitas Christi in hoc notatur, quia cenam fecit magnam). W ten zręczny sposób na plan pierwszy wysuwa się obraz uczty, który elektryzował uwagę balansującego na granicy głodu społeczeństwa średniowiecza. Teraz kaznodzieja w trzech odsłonach ukazuje wyobraźni odbiorców wizję wielkiej uczty (magna cena), której uczestnicy zostaną w pełni nasyceni z powodu niezliczonej ilości dań, które zostały na nią przygotowane, a sama zaś obecność na niej ma dać radość nieporównywalną z żadną spośród tych znanych na ziemi. Poświadczać to mają stosowne fragmenty Ksiegi Ezdrasza, Księgi Liczb, symbolika owoców oraz popularne egzemplum o pewnym zakonniku.

Pokaźna ilość miejsca, które poświęcono samej uczcie, może się wydać dziwna w zestawieniu z wcześniej wymienioną $\mathrm{w}$ divisio hierarchią wartości: wszak to podmioty powinny górować nad miejscem i okolicznościami. Peregryn jednak zaznacza, że w rzeczywistości pochwała uczty jest dowodem hojności Gospodarza-Chrystusa, przywołując Jego postać w samym środku opisu.

Na marginesie należy odnotować, że hojność (largitas) od czasów karolińskich zrosła się z władzą świecką i była postrzegana jako cnota wyróżniająca wielkich feudałów, której przeciwstawiano pogardzane skąpstwo chłopów. W tym świetle Chrystus jawi się jako ideał dobrego pana i władcy, co przybliża Jego postać wiernym i czyni ją łatwiejszą do wyobrażenia.

Rozwinięcie pierwszego punktu tematu - tj. hojności - zamyka wizja Chrystusa zapraszającego na ucztę na cztery sposoby, co w połączeniu $\mathrm{z}$ trzema odsłonami samej uczty daje razem siedem - wieloznaczną liczbę świętą. Jest to dowód, że ta część kazania została zaplanowana i zarazem starannie przeprowadzona.

Następuje teraz przejście do rozwinięcia drugiego punktu divisio, czyli ukazania przewrotności tych, którzy nie przyjęli zaproszenia na ucztę. Jak już wiemy, jest to odwołanie do dalszej części przypowieści, z której Peregryn tylko pierwszy werset zacytował jako temat. Z tego względu przytacza on teraz potrzebny do zrozumienia dalszy fragment Ewangelii i jednocześnie go interpretuje. I tak znów mamy do czynienia z symboliczną trójka, bo oto trzech wymawiających się od przyjścia na ucztę gości objaśnionych zostaje jako trzy z tzw. grzechów głównych. Są to: pycha (superbia), uchodząca w średniowieczu za królową grzechów, bo w niej upatrywano początek pozostałych wad oraz na dalszych miejscach: chciwość (avaritia) i rozpusta, czyli nieczystość (luxuria).

Następnie Peregryn dodaje dwa rozbudowane egzempla, prezentujące różne rodzaje wad. Pierwsze z nich wymienia aż sześciu bohaterów, symbolizujących sześć grzechów głównych, drugie zaś piętnuje jedynie cudzołóstwo. Podliczmy: trzy grzechy z interpretacji przypowieści, 
sześć grzechów z pierwszego egzemplum i jeden z drugiego dają w sumie dziesięć-jedną z ulubionych w średniowieczu, bo wieloznacznych, liczb3.

Pod drugim egzemplum widnieje już tylko krótka formuła kończąca kazanie (unitio).

Widzimy teraz, że kazanie zostało starannie zaplanowane. Dwa główne punkty z dilatatio prezentują dwa podmioty w dwóch częściach kazania. Pierwsza partia poświęcona jest Bogu i zorganizowana wewnętrznie według świętej liczby siedem; natomiast druga ukazuje dziesięć odsłon grzeszników (podmiot zbiorowy), a dziesiątkę w tym wypadku odczytać można jako symbol mnogości, bo tak też w średniowieczu, przez zaokrąglanie do dziesiątek, setek i tysięcy, oddawano wrażenie wielości. Dodatkowy, pomocniczy punkt dilatatio, którym było uwypuklenie miejsca i okoliczności uczty, nie przysłonił nadrzędnej pozycji obu podmiotów, czyli jej uczestników, chociaż możemy założyć, że musiał mocno ożywiać wyobraźnię audytorium.

W tym kazaniu uwagę przykuwa jednak nie tylko wizja wielkiej uczty. Zdecydowanie bowiem wyróżnia się także właśnie owo przedostatnie egzemplum ukazujące sześciu grzesznych bohaterów. Po pierwsze dlatego, że jest to najobszerniejsza z części składających się na to kazanie. Po drugie, z powodu niezwykłej treści.

Musiała ona być również niebanalna dla Peregryna z Opola, skoro bezpośrednio poprzedził ją dwoma zabiegami. Oto pierwszy z nich: „Czytamy, że Rzymianie czcili jako boga Saturna, który jest nazywany »urodzajnym «, czyli »sytym rokiem «. Czynili tak dlatego, aby im zapewnił urodzajny rok".

Peregryn czuł tu potrzebę wyjaśnienia mitologicznego pochodzenia postaci, która pojawi się w egzemplum, oraz wskazania archaicznej i tylko literackiej już jej proweniencji owym krótkim „,czytamy, że" (legitur, quod). Drugi zabieg polega na odwołaniu się do autorytetu, tzn. w tym wypadku umocnieniu całego egzemplum toposem mędrca: „pewien mędrzec pisze” (de isto scribit quidam sapiens).

Teraz dopiero następuje właściwa fabuła: „Saturn urządził wielką ucztę i zaprosił na nią wszystkie stworzenia tego świata. Kiedy uczta była już przygotowana, przybyły wszystkie zaproszone zwierzęta, z wyjątkiem sześciu, które wzgardziły zaproszeniem. Pierwsza była świnia, która się wymawiała, mówiąc: »Jeżeli na uczcie nie będzie strąków i plew do jedzenia, a brudnej wody do picia, nie przyjdę«. Drugi był kruk, który odpowiedział: »Jeżeli nie będzie tam trupów do rozdziobania, nie przyjdę«. Trzecia była sowa, która odpowiedziała: »Jeżeli nie ma tam ciemności, nie przyjdę«. Czwarta była żaba, która się wymówiła: »Jeżeli nie będzie tam mułu do jedzenia, nie przyjdę«. Piąty był lis, który odpowiedział: »Jeżeli nie będzie tam stworzeń, które mógłbym oszukiwać, nie przyjdę«. Szósta była mucha, która odpowiedziała: »eżeli nie ma tam nieczystości, w których mogłabym się paprać, nie przyjdę«".

Dalej następuje rozległa eksplikacja egzemplum. I tak według kaznodziei Saturn to Filius Dei, Syn Boży. Świnia (porcus) to ludzie lubujący się w grzechu pychy, rozpusty, chciwości, gniewu i innych występkach. Kruk (corous) to złodzieje, łotrzy i wyzyskiwacze. Sowa (noctua) to oszczercy i mąciciele, a ich zły język (mala lingua) to najgorsza część ciała. Tu też Peregryn przytacza słynny koncept Ezopa, który posłany przez swego pana na targ po najlepsze, a potem najgorsze mięso, każdorazowo kupuje ozory. Następująca dalej żaba (rana) to chciwość, która pociaga za sobą smutek, troski, głód, lichwę i nieustanne myśli o pieniądzach. Z kolei lis (vulpes) to czarownice i heretycy, używający „pięknych słodkich słów, którymi oszukująi zwodzą człowieka jak lis, który chwalił kruka, aby zdobyć ser". Ostatnia zaś mucha (bruchus) oznaczać ma cudzołożnika, który woli leżeć w brudach pod płotem niż ze swoją żona, bo - jak pisze kaznodzieja - „podobnie czyni mucha, która lecąc przez zieloną łąkę, unika pięknych kwiatów, a ciąnie do cuchnącego gnoju" (in fortido fimo).

3 Na temat symboliki liczb: M. Lurker, Stownik obrazów i symboli biblijnych, Poznań 1989; lub: D. Forstner, Świat symboliki chrześcijańskiej. Leksykon, Warszawa 2001.

OGRODY NAUK I SZTUK NR 2012 (2) 
Wprowadzanie egzemplów do kazania nie było ówcześnie niczym nadzwyczajnym. Czynili tak już Ojcowie Kościoła, wśród których Tertulian (zm. ok. 220 r.) uchodzi za prekursora tej techniki w piśmiennictwie chrześcijańskim ${ }^{4}$. Należy także wspomnieć wpływową Księgę reguły pasterskiej autorstwa Grzegorza Wielkiego, który nakazywał w niej dopasowanie kazania do poziomu umysłowego odbiorców i ograniczenie dowodów rozumowych do ludzi mądrych, podczas gdy pozostałych lepiej powinny przekonać przykłady ${ }^{5}$. Także teoretycy artes praedicandi w XIII W., kontynuując spuściznę antyczna, doradzają używanie różnych, pouczających przykładów.

Wielu badaczy kaznodziejstwa średniowiecznego widzi rolę egzemplów w ułatwianiu zrozu-

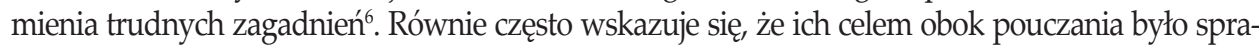
wianie przyjemności ${ }^{7}$, co ma nawiązywać do retoryki antycznej i zasady docere - delectare, utożsamianych obecnie z funkcją informująco-pouczającą oraz z funkcją estetyczną. Pamiętamy jednak, że w retoryce antycznej mowa składała się z trzech elementów (tria officia dicendi): docere - movere - delectare. Ten brak wskazania funkcji movere, któremu odpowiada obecnie tzw. funkcja zniewalająca, jest $\mathrm{w}$ pismach polskich badaczy dość powszechna. Wyjątek stanowi wytrawny badacz kaznodziejstwa, Jerzy Wolny9. Tymczasem czołowy autorytet doby średniowiecza, św. Augustyn, w podręczniku dla kaznodziejów - De doctrina christiana - pisze: „Kiedy jednak słuchaczy należy raczej poruszyć niż pouczyć, by nie ociągali się z wykonaniem tego, co już znaja, a także by w nich utrwalić przekonanie co do rzeczy już uznawanych za prawdziwe, potrzebna jest większa siła wymowy. Wtedy konieczne są zaklęcia, groźby, zachęty, ostrzeżenia przed karą oraz wszelkie środki zdolne poruszyć umysł” (valent ad commovendos animos) (Ks 4, IV-6) ${ }^{10}$. Zwróćmy uwagę na te „wszelkie środki zdolne poruszyć umysł" i przyjrzyjmy się wymienionym przez Peregryna zwierzętom.

Symbolika zwierząt $w$ średniowieczu była zmienna i uwarunkowana kontekstem. Dla przykładu: kiedy znalazły się na monetach postrzegano je zawsze pozytywnie, chociaż ich pojawianie się w innych miejscach, jak choćby w kazaniu, mogło być odebrane różnie i dlatego konieczny w takim wypadku był komentarz. Są jednak i takie gatunki fauny, które miały zdecydowanie złą reputację. Do nich należy właśnie świnia, kruk, sowa, żaba, lis i mucha ${ }^{11}$. Ich wybór do prezentacji grzechów ludzkości wydaje się niezwykle trafny. Ponadto w interpretacji alegorycznej przydanej do egzemplum (tzw. moralisatio) Peregryn nie ogranicza się tylko do prostego połączenia zwierzęcia z grzechem, ale też stara się uwypuklić negatywne jego cechy, pogłębiając tym siłę negatywnego obrazu, co z pewnością wywierało na audytorium mocniejsze wrażenie. W ten sposób realizował on ów trzeci człon antycznej zasady, mianowicie movere. W istocie bowiem celem kazania było wstrząśnięcie sumieniami wiernych ${ }^{12}$.

Jednak już Augustyn ostrzegał przed niebezpieczeństwem powierzchowności przemiany ducha pod wpływem używania stylu wysokiego, opartego na emocjach. Zwracał przy tym uwagę, że kiedy minie pierwszy afekt, w umyśle słuchaczy nie pozostanie nic z całej mowy.

\footnotetext{
4 K. Panuś, Historia kaznodziejstwa, Kraków 2007, s. 144.

5 Grzegorz Wielki, Księga reguly pasterskiej, Poznań 1948, s. 98.

6 T. Szostek, Exemplum w polskim średniowieczu, Warszawa 2007, s. 13.

B. Geremek, Exemplum i przekaz kultury, [w:] tenże (red.), Kultura elitarna a kultura masowa wo Polsce późnego średniowiecza, Wrocław 1978, s. 75

8 M. Korolko, Sztuka retoryki. Przewodnik encyklopedyczny, Warszawa 1990, s. 46-47.

9 J. Wolny, Exempla z kazań niedzielnych Peregryna z Opola, [w:] B. Geremek (red.), dz. cyt., s. 247.

Św. Augustyn, De doctrina christiana. O nauce chrześcijańskiej, Warszawa 1989.

1 Zob. S. Kobielus, Bestiarium chrześcijańskie. Zwierzęta w symbolice i interpretacji. Starożytność i średniowiecze, Warszawa 2002

12 Św. Augustyn, dz. cyt, s. 214-215.
} 
Rozwiązanie tego trudnego problemu przynosiła również tradycja retoryki antycznej, a konkretnie dział zajmujący się pamięciowym opanowaniem treści, tzw. sztuka pamięci (ars memorativa). Jak dowiodła Frances Yates, sztuka ta tylko pozornie była nieobecna w wiekach średnich. W rzeczywistości zaś dobrze znano podręcznik Ad Herrenium, aczkolwiek nazywano go Drugą Retoryka, gdyż błędnie uznawano Cycerona za autora i czytano razem z autentycznie jego tzw. Pierwszą Retoryką. Jak pisze F. Yates: „Łączenie ze sobą tych dwóch dzieł miało ogromne znaczenie dla zrozumienia formy, jaką przyjęła sztuczna pamięć w Średniowieczu. Wszak Tulliusz w Pierwszej Retoryce kładzie duży nacisk na etykę i na cnoty jako »wynalazki« czy »rzeczy«, a w Drugiej podaje reguły co do sposobu, w jaki te »rzeczy należy przechowywać w skarbcu pamięci«"13.

Dla nas najważniejszą z podanych tam reguł jest teoria tzw. images agentes, co w wolnym przekładzie można oddać jako „obrazy oddziaływujące na wyobraźnię", a oznaczało to metodę łączenia tekstu $\mathrm{z}$ dosadnym wyobrażeniem, co ułatwiało zapamiętywanie. Teoria ta została podjęta w XIII w. m.in. przez Tomasza z Akwinu, bo też dobrze przystawała do potrzeb ówczesnych teoretyków ze względu na wspomniany wpływ tzw. Pierwszej Retoryki, przez którą images agentes uległy „moralizacji”. W praktyce oznaczało to posługiwanie się skojarzeniami pięknymi lub szkaradnymi do łatwiejszego zapamiętania duchowych pojęć.

Warunki te dobrze spełniają zwierzęta z egzemplum użytego przez Peregryna z Opola. Świnia, kruk, sowa, żaba, lis i mucha to zbiór bardzo dobrze znany mieszkańcom Europy. Jeszcze ważniejsze jest to, że zbiór ten wywołuje emocje, a więc spełnia funkcję poruszenia umysłów (movere). Dotyczy to nawet świni, która jako jedyne hodowlane zwierzę z tej grupy, mogłaby konotować materialną korzyść. Jednak w tym wypadku wydaje się, że oprócz cech behawioralnych, na negatywnym postrzeganiu świni zaważyła również tradycja judaistyczna, a ściśle rzecz biorąc - Biblia, w której jest ona uznawana za istotę nieczystą. Dzięki rozpoznawalności i ładunkowi emocjonalnemu zwierzęta te nadają się do stworzenia wywoławczej bazy w pamięci, na której zostanie nadbudowana treść trudniejsza, bo abstrakcyjna. W tym konkretnym wypadku jest to, zgodnie z drugim punktem dilatatio, ukazanie przewrotności ludzi odrzucających zaproszenie Chrystusa, czyli po prostu napiętnowanie grzechu.

I tu również ważne jest to, że w kazaniu Peregryna z Opola samo egzemplum nie kłóci się $\mathrm{z}$ moralisatio, a wręcz przeciwnie - komentarz potęguje wrażenie przez dodane tu kolejne plastyczne elementy takie, jak: stajnia, oczy wbite w ziemię, brudy pod płotem czy cuchnący gnój. W sumie czyni to tę partię kazania czytelna, spójną i dosadną zarazem, a dzięki temu udzielona przez Peregryna nauka o rodzajach grzechu jest łatwiejsza do zapamiętania.

Przeprowadzona tu analiza kazania Peregryna z Opola pokazuje warsztat tego autora i dowodzi jego dobrej znajomości trudnej sztuki kaznodziejskiej. Strukturalne zorganizowanie tekstu zdradza staranne zaplanowanie treści, a odpowiednie wprowadzenie plastycznej sceny uczty wskazuje na dużą wprawę. W tym kontekście wydaje się, że przywołane przez niego sugestywne i rozbudowane egzemplum o zwierzętach zaproszonych na ucztę nie może pełnić jedynie funkcji odprężającej słuchaczy (delectare). Funkcję tę można co najwyżej uznać tu za efekt poboczny, gdyż głównym celem podobnego zabiegu jest oddziałanie na wyobraźnię odbiorców (movere) oraz utrwalenie wiadomości poprzez rodzaj plastycznego skrótu, w czym można upatrywać kontyuację antycznej sztuki pamięci i realizację metody images agentes.

13 F. A. Yates, Sztuka pamięci, Warszawa 1977.

OGROdY NAUK I SZTUK NR 2012 (2) 


\section{LITERATURA PODMIOTU}

Św. Augustyn, De doctrina christiana. O nauce chrześcijańskiej, przekł. J. Sulowski, Warszawa 1989.

Grzegorz Wielki, Księga reguty pasterskiej, przekł. J. Czuj, Poznań 1948.

Peregrini de Opole, Sermones de tempore et de sanctis, wyd. R. Tatarzyński, Warszawa 1997.

Peregryn z Opola, Kazania „,de tempore" $i$ "de sanctis", przekł. J. Mrukówna, Kraków-Opole 2001.

\section{LITERATURA PRZEDMIOTU}

Geremek B., Exemplum i przekaz kultury, [w:] tenże (red.), Kultura elitarna a kultura masowa w Polsce późnego średniowiecza, Wrocław 1978.

Kobielus S., Bestiarium chrześcijańskie. Zwierzęta w symbolice i interpretacji. Starożytność iśredniowiecze, Warszawa 2002.

Korolko M., Sztuka retoryki. Przewodnik encyklopedyczny, Warszawa 1990.

Panuś K., Historia kaznodziejstwa, Kraków 2007.

Szostek T., Exemplum w polskim średniowieczu, Warszawa 2007.

Wolny J., Exampla z kazań niedzielnych Peregryna z Opola, [w:] Geremek B. (red.), Kultura elitarna a kultura masowa w Polsce późnego średniowiecza, Wrocław 1978.

Wolny J., Łaciński zbiór kazań Peregryna z Opola i ich zwiazek z tzw. „Kazaniami gnieźnieńskimi”, [w:] Lewański J. (red.), Średniowiecze. Studia o kulturze, Warszawa 1961.

F.A. Yates, Sztuka pamięci, przekł. W. Radwański, Warszawa 1977.

\section{STRESZCZENIE}

Niniejszy artykuł pokazuje funkcjonowanie sztuki pamięci w twórczości Peregryna z Opola. Na podstawie analizy jednego z kazań tego autora możemy dostrzec obecność antycznej techniki zwanej imagines agentes.

Słowa kluczowe: Peregryn z Opola, kazanie, ars praedicandi, egzemplum, ars memorativa, imagines agentes.

\section{“...JUSt LiKe When you MaKe A Wax SEAL": MNemotechnique in Peregryn's SERMONS}

\section{Summary}

This article demonstrates the function of ars memorativa in the works of Peregryn from Opole. Analyzing one of his sermon, we can see the presence of an ancient technique called imagines agentes.

Key words: Peregryn from Opole, sermon, ars praedicandi, exemplum, ars memorativa, imagines agentes. 